\title{
FROM AN EMPIRICAL TO CONCEPTUAL MODELING VIEW OF ENERGY CROP PRODUCTIVITY
}

\author{
ŠIMKŪNAS, A.* - DENISOV, V. - VALAŠINAITĖ, S. - JANKAUSKIENĖ, R. - IVANAUSKAITĖ, A. \\ Marine Technology and Natural Sciences Faculty, Klaipeda University, Klaipėda, Lithuania \\ *Corresponding author \\ e-mail: alvydas.simkunas@gmail.com; phone: + 370-861-701-993
}

(Received $19^{\text {th }}$ Jan 2018; accepted $13^{\text {th }}$ Mar 2018)

\begin{abstract}
When empirical research provides incomplete data, it is often not accepted, especially if the primary data is slightly controversial. This article investigates this situation exactly, where there is little data and quite unexpected results. A conceptual modeling approach is applied here to supplement the empirical research and to examine the yield obtained from the Silphium perfoliatum energy plant under certain environmental conditions in Lithuania. The designed conceptual model is based on an analysis of informational relationships within the "donor-acceptor" ("source-sink") plant (sub)system. It was found, that the chlorophyll- $a$ amount did not affect the yield, what according to the model, may be determined by the different acceptor activity. Nitrogen and potassium influenced the biomass positively, possibly through the activation of acceptor metabolism and assimilate transport, and the consequent signaling on the photosynthetic apparatus (via cytokinin and sugar). Meanwhile, the high phosphate amount in soil negatively influences the yield. A hypothesis of yield limitation by signaling through the high phosphate levels in the case of slowed down photosynthesis is proposed. In addition to determining the causality of the yield formation, the conceptual modeling enables us to make use of limited empirical data to design future experiments, aimed at testing the hypothesis and verifying the model.
\end{abstract}

Keywords: energy plant Silphium perfoliatum; yield formation conceptual model; system dynamics methodology; donor-acceptor causal relationships; yield inhibition via phosphate

\section{Introduction}

The list of crops grown both in Europe and in Lithuania is constantly supplemented with new, poorly investigated energy plants. These plants grow rapidly and create a large biomass, although because of economic and ecological reasons, they are grown in poorly cultivated soils (McKendry, 2002a; Jakienè et al., 2015; Allen et al., 2014). Not only is productivity important while growing such plants, but also their ecological impact, i.e. less harmful environmental impact. In seeking to obtain a sufficient yield in non-fertile soils, it is necessary to apply agricultural practices aimed at addressing the main yield-limiting factor, otherwise the yield sharply decreases. The same strategy (to affect the limiting factor) is applied while seeking to reach the proper ecological effect to minimize any impurities that pollute the environment and complicate the technological process. So we face challenges in achieving both a higher plant yield and a positive ecological effect.

One of the less investigated energy crops, Silphium perfoliatum L., is suitable for biochemical conversion, i.e. methane extraction via anaerobic digestion. This is achieved because of the large biomass of this plant and its easily degraded materials, i.e. the stems are filled with a spongy core. The average yield of $S$. perfoliatum is 13-15 t/ha, and high yields may be obtained up to 15-17 t/ha (Gansberger et al., 2015). So the dry matter yield per hectare of $S$. perfoliatum may be approximately equal to that of maize, while some authors reported an approximately $20 \%$ lower yield per hectare for $S$. perfoliatum than for maize (Aurbacher et al., 2012). Meanwhile, other authors reported 
(Stockmann et al., 2013) a 20-50\% lower yield per hectare for S. perfoliatum than for maize. While growing these plants, it is also important to be aware of the ecological impact during the methane extraction process - slag formation, which depends on the biomass ash content. The following impurities could be present: particulates, tar, N, S and alkali compounds. The problem of slag formation is caused by the alkali content of the biomass (McKendry, 2002b). So while growing S. perfoliatum, it is important to pay attention to the yield increase along with its quality.

Up until now, plenty of empirical data has been accumulated about energy crop yield formation accomplished through the use of fertilizers, liming soils, etc. (Douglas et al., 1987; Wrobel et al., 2013; Siaudinis et al., 2012). Many authors also suggest that further research is needed in the following directions: first year trial equipment optimization, control of weeds and pests, opportunities to use a form of different geographical origin for both economic activity and plant-breeding, and the application of energy plants (incl. S. perfoliatum) in medicine (Kowalski and Wolski, 2003; Gansberger et al., 2015). However, up until now, the empirical viewpoint has prevailed in the field research of energy plants, so the typical results obtained lack an explanatory nature and (eco) system level conceptualisation (Adegbidia et al., 2001; Borkowska et al., 2009; Maughan et al., 2012; Jasinskas et al., 2014; Šiaudinis et al., 2015). They are not oriented enough towards the causality of agroecosystem processes and their interconnections. Such an examination of individual processes encompasses a broad spectrum of topics and a great number of unrelated experiments and field trials.

When empirical research provides little or incomplete data, it is often not accepted, especially if the primary data is even slightly controversial. This article investigates this situation exactly, where there is little data or quite unexpected results (for example, when a significant correlation between chlorophyll concentration and biomass is absent, or when the phosphate concentration in a soil has a negative influence on biomass). A systemic conceptual approach, which is applied here to examine the yield obtained from the $S$. perfoliatum energy plant under certain environmental conditions, is based on an analysis of informational relationships that are important for photosynthesis control within the "donor-acceptor" ("source-sink") plant (sub)system. The resulting causal model of yield formation includes both internal (donor-acceptor) and external (fertilization, illumination, etc.) factors, which enables us to analyse all the experimental field results from the chosen conceptual viewpoint. Moreover, the conceptual model itself can be further formalized and refined, constructing a simulation model, which can then be investigated in computer experiments in order to supplement weak empirical data with a new set of synthetic data. To sum up, the representation of sparse or incomplete empirical data via a conceptual model can help in identifying the origins of contradictions, to reveal their significance, to explain causality of factors, and thus, to provide more added value to the research results.

The underlying concept of "donor-acceptor" ("source-sink") applied here takes into account that the photosynthesis and yield formation processes directly depend on the activity of a leaf, as a donor (source) of photoassimilates (Rossi et al., 2015; Yu et al., 2015). Meanwhile, it is known that the intensity of photosynthesis is also regulated via signals related with the acceptors (sink), i.e. areas involved in the metabolic activities of growing and reserving (Mokronosov, 1981; Nancy, 1994; Chikov, 2008; Paul and Foyer, 2001; Fatichi et al., 2014; Yu et al., 2015; Rossi et al., 2015). In particular, the latter is confirmed by positive correlations detected between photosynthetic activity and the acceptors' growth indices (relative and absolute growth rate) (Mokronosov, 1981). It 
is also known that some photosynthesis genes (Rubisco small subunit, plastocyanin genes, etc.) are turned off by feedback control loops when carbohydrates are not used enough in acceptors, and they accumulate in the leaves (Paul and Foyer, 2001; Tognetti et al., 2013). The main signal substances in this regulation network are soluble carbohydrates, mostly sucrose. Meanwhile, photosynthesis throughout the entire plant level is regulated from other parts of the plant system, i.e. acceptors, and the productivity of photosynthesis depends to a great extent on systemic determination.

It is important to keep in mind that photosynthesis may be limited by any component of the "donor-acceptor" system, and it depends on specific environmental conditions the amount of light, water content in the soil, and mineral nutrition components (Mokronosov, 1981; Brown, 1988; Rossi et al., 2015). From the donor side, the limitation of photosynthesis is possible because of insufficient light, or when the $\mathrm{CO}_{2}$ fixation becomes insufficient and limits the growth and yield. It should be mentioned that in a situation when the amount of sugar is not sufficient, growth is not reduced directly, but through regulatory mechanisms, i.e. SNrK1 kinase activation, thus, growth is suppressed and adapted to the donor potency (Lastdrager et al., 2014; Yu et al., 2015). Alternately, when the donor activity and sucrose amount increase, the amount of signal carbohydrate trehalose 6-phosphate (T6P) also increases, which indicates good donor functioning and inhibits the kinase SNrK1 activity, thus stopping the suppression of growth. Photosynthesis can be also limited through the growth limitations of acceptors, and this can be caused by different factors (for example, a phosphates deficit) (Rychter and Rao, 2005; Lawlor and Paul, 2014). In this case, a smaller amount of sugar is used, and photosynthesis slows down because of feedback control. It is also important to note that the interaction between donor and acceptor changes during ontogenesis, for example, during the later ontogenesis phases, an entirely new group of acceptors, i.e. generative structures, are formed. Then, with the assimilates more oriented towards inflorescence, root nutrition may suffer, which slows down photosynthesis and limits the yield (Mokronosov, 1981; Chikov, 2008) Thus, the systemic determination of photosynthesis is non-static, i.e. it changes through the influence of both environmental conditions and ontogenetic drift.

The study deals with the following research issue: which of the investigated system components, i.e. either donor or acceptor, limits the yield of an S. perfoliatum energy crop under the influence of specific environmental conditions (Lithuanian climate, Cambisols, different soil NPK in the experimental plots). The aim of the study is to design a conceptual model of the $S$. perfoliatum energy plant's productivity, enabling the identification of such limiting components and to delineate further research directions for it. In particular, the study will assess the relationships of the chlorophyll content within the $S$. perfoliatum biomass and the influence of the amount of root nutrition medium indices (general amounts of nitrogen, mobile phosphorus and potassium available) to the $S$. perfoliatum biomass. It will also compare the influence of different factors (chlorophyll content in the leaves and nitrogen, phosphorus and potassium present in the soil) to $S$. perfoliatum productivity. As already mentioned, the primary data from the experimental fields is incomplete and somewhat controversial, however, at the same time, is quite interesting and provocative, inviting further interpretation. To make use of it, it is combined with known physiological assumptions to produce a conceptual model of energy plant productivity, based on the analysis of informational relations that are important for the control of photosynthetic productivity within the "donor-acceptor" ("source-sink") plant (sub)system. 


\section{Materials and methods}

\section{The object and location of investigation}

The object of investigation was the cup plant (Silphium perfoliatum L.), which belongs to Asteraceae family (Wrobel et al., 2013). It is a perennial $\mathrm{C}_{3}$ plant, which is used as an energy crop. The possibility of using this plant in biogas production has been determined by its botanical characteristics, i.e. its large biomass, as each plant grows 10-25 stalks, having 8-12 internodes with a length of 20-30 cm (Wrobel et al., 2013). Its easy degradation is ensured by the spongy core that fills the stalks.

The experiment location - Lithuania, Šiauliai district, Bubiai eldership, Bagdoniškès village. Coordinates: 55.766919, 23.1864474.

Although native to North America, S. perfoliatum has also adapted to different European climates (Kowalski and Wolski, 2003; Stanford, 1990). The optimal growth temperature for these plants is about $20^{\circ} \mathrm{C}$, although they survive under the temperature as low as $-30^{\circ} \mathrm{C}$ (Stanford, 1990; Gansberger et al., 2015). These plants grow mainly in places with high air humidity and soil moisture (Stanford, 1990; Gansberger et al., 2015). Its very strong root system $(30-150 \mathrm{~cm}$ in length) allows $S$. perfoliatum to survive during drought periods (Stanford, 1990; Grebe et al., 2012; Schoo et al., 2013). The minimum water requirement is around $400-500 \mathrm{~mm}$ per year and $200-250 \mathrm{~mm}$ per vegetation period, similar to maize (Grebe et al., 2012). This plant has also been introduced in Lithuania, where both the temperature and precipitation amounts (600-650 $\mathrm{mm}$ in the experimental area) are proper for its cultivation.

Currently, only seeds of a different geographical origin are available, but no approved varieties with typical characteristics (Biertümpfel et al., 2013; Grebe et al., 2012). S. perfoliatum has a wide genetic range. In our case, the seeds were obtained from Germany.

\section{Plant growing and the study area selection}

Seedlings were grown in cassettes with a substrate composed of peat, sand and compost soil (at a ratio 2:1:1). The cassettes were kept in a greenhouse about 60 days till the stage of three-four leaves. Then the seedlings were planted in soil (at the end of June). Plants were not applied with fertilizers, and were watered only in the greenhouse. The yield was taken in the second and third year. This paper examines the third year yield.

Two fields, named A and B, were chosen for growing S. perfoliatum and the same conventional cultivation process applied in each field. Two plots with plants of different size were chosen for each field to study the differences in yield. After this, the plots were named I, II (from field A) and III, IV (from field B). Each plot covered $3 \mathrm{~m}^{2}$. The plots were divided into 3 parts, each part being $1 \mathrm{~m}^{2}$, and samples of soil, leaves and green mass were taken from them.

\section{Plant leaves, soil and plant biomass samples collection}

S. perfoliatum leaves were taken from the investigated plots (I, II, III, IV), seeking to identify the concentrations of chlorophyll. Three leaf samples were randomly picked from each plot (one from each $1 \mathrm{~m}^{2}$ plot area). The samples were taken from the same apical positions of the plants. Samplings were made 3 times during 2014: on September $18^{\text {th }}$, September $25^{\text {th }}$ and October $2^{\text {nd }}$.

Soil samples were taken from investigated plots I, II and IV, seeking to identify the soil $\mathrm{pH}$, granulometric composition and total nitrogen, mobile potassium and 
phosphorus amounts. To form the samples, $20 \mathrm{~cm}$ of the upper soil layer were taken from each plot (one from each $1 \mathrm{~m}^{2}$ plot area), and a common sample for each entire plot was formed. The soil samples were taken on July $1^{\text {st }}, 2014$.

The $S$. perfoliatum green mass yield from plots I, II, III and IV was estimated on October $2^{\text {nd }}, 2014$. Three green mass yields were cut from each plot and weighed (one from each $1 \mathrm{~m}^{2}$ plot area).

\section{Determination of chlorophyll a concentration, soil sample investigation and biomass weighing}

The concentration of chlorophyll in the $S$. perfoliatum leaf tissues was estimated according to the protocol of Hiscox and Israelstam (1979). The chlorophyll was extracted using dimethyl sulfoxide (DMSO) and quantified by spectrophotometry at the $645 \mathrm{~nm}$ and $663 \mathrm{~nm}$ wavelengths. The concentration of chlorophyll a was expressed in $\mathrm{g} / \mathrm{l}$ of fresh weight using the following equation: $(\mathrm{g} / \mathrm{l})=0.0127 \times \mathrm{A} 663-0.00269 \times$ A645 (Arnon, 1949; Eleuch et al., 2012).

The soil $\mathrm{pH}$ was estimated in a $1 \mathrm{~mol} / \mathrm{l} \mathrm{KCl}$ suspension. The concentrations of total nitrogen $(\mathrm{N})$, mobile phosphorus $\left(\mathrm{P}_{2} \mathrm{O}_{5}\right)$ and mobile potassium $\left(\mathrm{K}_{2} \mathrm{O}\right)$ were estimated by the acetate-lactate Egner-Riem-Doming (A-L) method, as this method is the most appropriate for potassium and phosphorus detection in sandy loam soils (Mažvila et al., 2006). The research results were obtained from air-dry soil samples at the Agrochemical Research Laboratory (Lithuanian Research Center for Agriculture and Forestry).

The plant biomass was estimated, having cut the above-ground parts of all the plants growing in each $1 \mathrm{~m}^{2}$ and measuring their fresh weight with a balance. The data obtained was expressed in $\mathrm{kg} / \mathrm{m}^{2}$. As the water requirements were equally fulfilled in the investigated plots, the measured fresh weight differences should reflect the differences of dry mass as well.

\section{Statistical analysis and the conceptual model design}

The yield of the investigated plots was evaluated using the ANOVA method. The criterion $p$ shows the significance of differences between the variants (plots), and the detected criteria of $\mathrm{LSD}_{0.05}$ and $\mathrm{LSD}_{0.01}$ allowed estimating the significance of the yield differences between the particular plots. The amount of chlorophyll a and amount of total nitrogen, mobile phosphorus and mobile potassium in the soil had an influence on the $S$. perfoliatum biomass, and this influence was estimated using the linear regression method.

The systemic conception of photosynthesis regulation was applied to perform the causal analysis of the yield formation process. It is based on the detailed analysis of the "donor-acceptor" relationships within the plant system (Mokronosov, 1981; Lerbs et al., 1984; Hirel et al., 2007; Paul and Foyer, 2001; Sandmann et al., 2011; Rychter and Rao, 2005; Lemoine et al., 2013). The preliminary conceptual model of the yield formation was created, in which the causal relationships were represented by the material and informational flows between the identified system components.

\section{Results}

The green matter of the $S$. perfoliatum yield in the investigated fields was estimated. The results of the ANOVA statistical method showed that the growing location influenced the yield: $\mathrm{p}=0.033(<0.05)$ (Fig. 1). To estimate the significance of the 
yield differences between the fields, the $\mathrm{LSD}_{0.5}$ and $\mathrm{LSD}_{0.1}$ statistical indices were calculated. Based on this criterion, the statistically significant yield differences were determined for the I and III plots ( 0.05 significance level) and between the I and IV plots (0.01 significance level) (see Fig. 1).

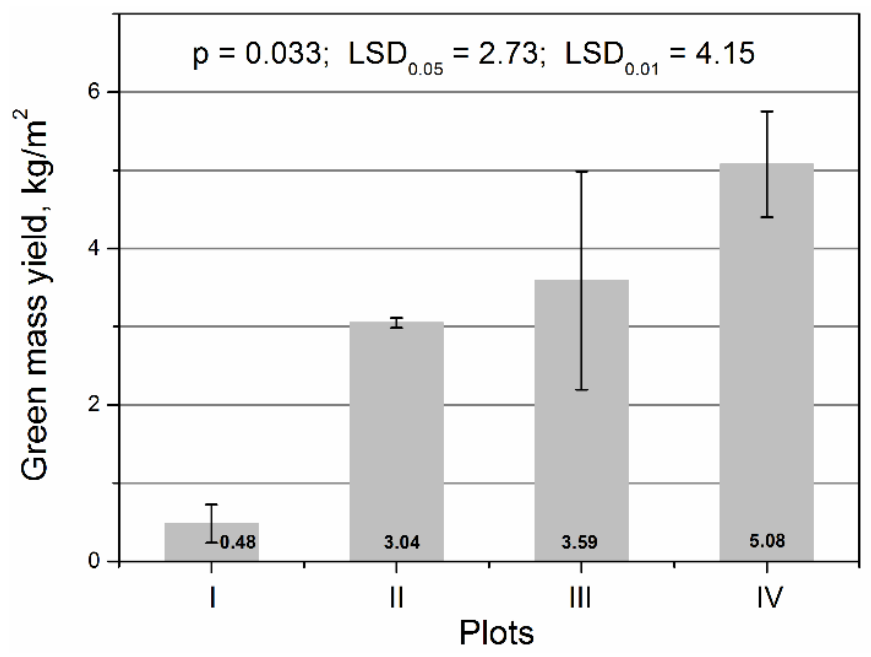

Figure 1. Green mass yield of S. perfoliatum in the investigated fields. The standard errors of the mean are shown

During the vegetation period, the assimilate donor (leaf) characteristic, chlorophyll a concentration, was estimated dynamically; the measurements were made 3 times (Table 1, Fig. 2). It was found that the chlorophyll a concentration had influenced the $S$. perfoliatum biomass insignificantly (the yield correlation indices from the different chlorophyll measurements: $r^{2}=0.106, r^{2}=0.198, r^{2}=0.0609$ ).

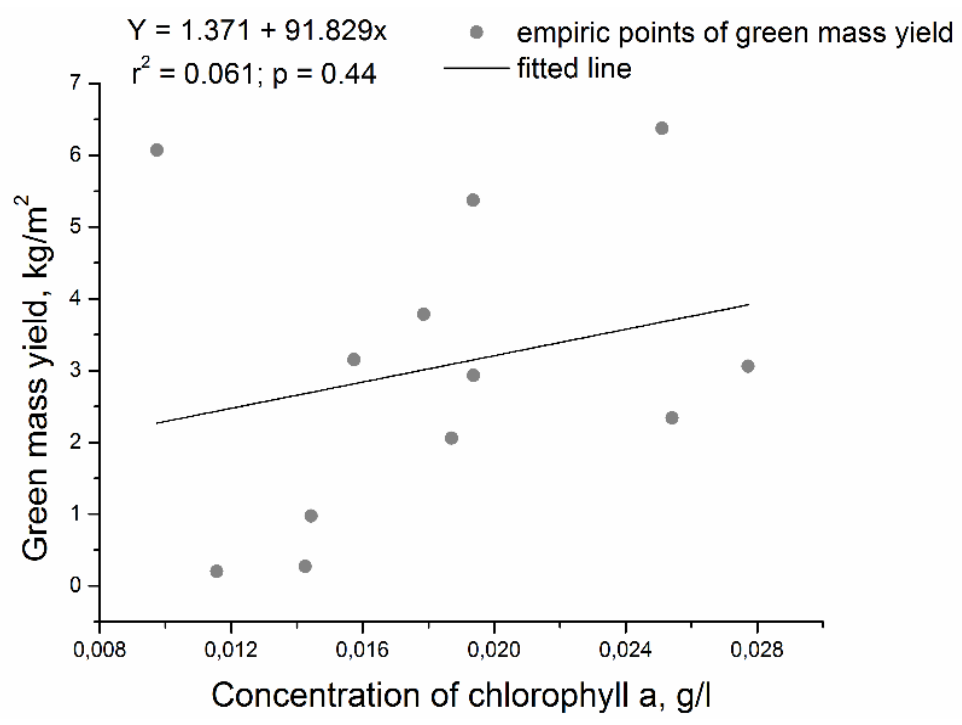

Figure 2. Green mass dependency on the chlorophyll a concentration found in the $S$. perfoliatum leaves (chlorophyll concentration on 201410 02) 
Table 1. The statistical indices of linear regression between the chlorophyll a concentration and green mass $(Y=a+b x)$

\begin{tabular}{c|c|c|c|c|c}
\hline $\begin{array}{c}\text { Date of } \\
\text { determination }\end{array}$ & $\mathbf{r}^{\mathbf{2}}$ & Slope $(\boldsymbol{b})$ & $\mathbf{P}(\boldsymbol{b})$ & Intercept $(\boldsymbol{a})$ & $\mathbf{P}(\boldsymbol{a})$ \\
\hline 20150918 & 0.106 & 228.708 & 233.884 & -1.875 & 4.526 \\
20150925 & 0.198 & 237.149 & 150.743 & -0.919 & 2.585 \\
20151002 & 0.0609 & 91.829 & 114.074 & 1.371 & 2.172 \\
\hline
\end{tabular}

The mineral nutrition factors, such as the concentrations of total nitrogen $(0.102-$ $0.118 \%)$, mobile potassium $(164-332 \mathrm{mg} / \mathrm{kg})$ and mobile phosphorus $(228-291$ $\mathrm{mg} / \mathrm{kg}$ ) in the soil of the investigated field plots were estimated. It was determined that the total nitrogen concentration in the soil had positively influenced the biomass of $S$. perfoliatum $\left(\mathrm{r}^{2}=0.58\right)$, the influence of the mobile potassium to biomass was also similar $\left(\mathrm{r}^{2}=0.55\right)$ (see Figs. $\left.3 A, 3 B\right)$. So the amount of the plant biomass was larger in the plots where the nitrogen and potassium concentrations in the soil were higher. Meanwhile, a higher mobile phosphorus concentration in the soil reduced the $S$. perfoliatum biomass $\left(\mathrm{r}^{2}=0.54\right)$ (see Fig. 3C).
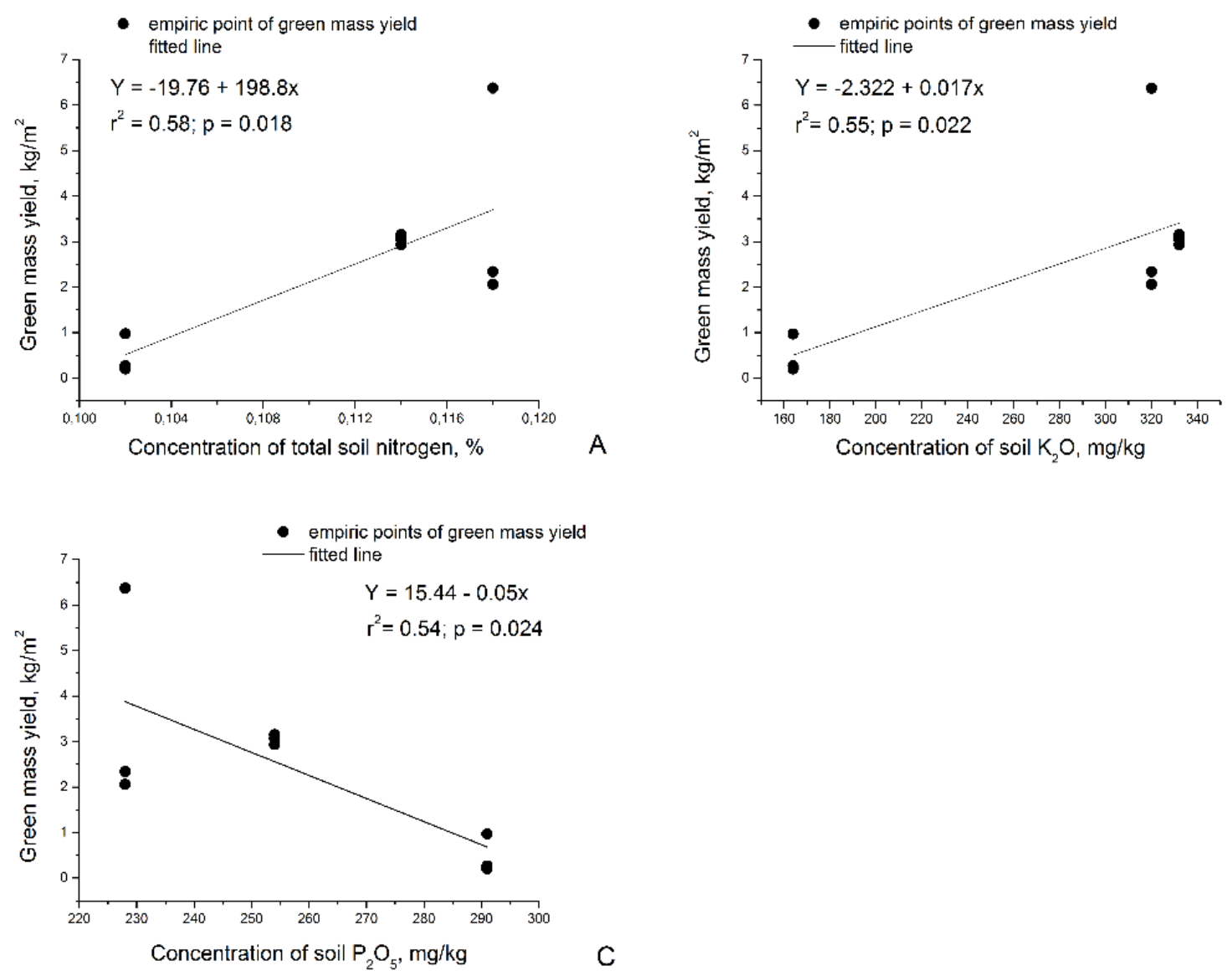

Figure 3. Green mass dependence on the nutrient concentrations in the soil: A-from the total nitrogen (\%), B -from mobile potassium ( $\mathrm{mg} / \mathrm{kg}$ ), $C$-from mobile phosphorus $(\mathrm{mg} / \mathrm{kg}$ ) 
In summarizing the results, it can be stated that the concentration of the light absorption component, chlorophyll a, influenced the yield of $S$. perfoliatum insignificantly. The influence of the mineral nutrition factors on the $S$. perfoliatum biomass was also estimated: the total nitrogen and mobile potassium concentrations influenced the biomass positively, whereas the mobile phosphorus concentration had a negative influence on the biomass.

\section{Discussion}

It was found that an important donor's characteristic, the chlorophyll a concentration, insignificantly influenced the yield of $S$. perfoliatum within the described limits (the determination coefficients of the three investigation periods were as follows: $r^{2}=0.106$, $\mathrm{r}^{2}=0.198, \mathrm{r}^{2}=0.0609$ ) (see Fig. 2; Table 1). This is a little contradictory of well-known facts regarding the correlation between chlorophyll concentration and biomass (Andrianova and Tarchevskii, 2000). Meanwhil, it does not contradict with another well-known fact, that the photosynthesis of $\mathrm{C}_{3}$ plants (such as $S$. perfoliatum) is not limited by summer illumination conditions, i.e. chlorophyll and light reactions have some reserve opportunities (Hall and Rao, 1994). The finding that the correlation between the chlorophyll a and biomass was absent and also the fact that there was no limitation by the air nutrition conditions lead to the assumption that the dispersion of the photosynthetic productivity of the $S$. perfoliatum energy plant at different chlorophyll a concentrations may be explained by other factors limiting photosynthesis and yield. This is a precondition in searching for an explanation by employing the systemic conception of photosynthesis regulation, which is based on the "donor-acceptor" relationships. The main hypothesis made by the authors is that the yield differences may be explained by the different acceptors' activity, which determines the photosynthesis through signalling (informational flows).

Thus, the conceptual modeling approach was employed by the authors for further analysis and interpretation of the yield formation process. To develop a conceptual model of the energy plant's productivity, both empirical results and physiological assumptions were used together with the known literature data available. The suggested causal conceptual model is presented in Figure 4A. The model causal loop diagram was created based on several sources; one of them is the conceptual scheme of A. T. Mokronosov (1981), which shows the relationships between the donor and the acceptor. To reveal the functioning of the donor and acceptor in more detail, the original scheme was expanded by including the influence of external factors (controlled and uncontrolled) previously discussed by other authors (Mokronosov, 1981; Lerbs et al., 1984; Nancy, 1994; Hirel et al., 2007; Paul and Foyer, 2001; Taiz and Zeiger, 2006; Sandmann et al., 2011; Rychter and Rao, 2005; Lemoine et al., 2013). The novelty of the proposed model is that it employs a methodology of systems dynamics modeling (Sterman, 2000) and makes a clear distinction between material and informational flows within the donor-acceptor system of the plant. Besides, comparing to the conceptual schemes mentioned above, it includes two new feedback loops, representing signalling through the levels of cytokinin and, especially, through phosphate.

An in-depth analysis of the interaction of individual components may require further refinement of the conceptual model's specifications. To accomplish this, it was proposed that very detailed diagrams of the plant's biochemical processes be summed 
up at a higher abstraction level. In particular, the authors summarized the detailed biochemical pathways of the photosynthesis-phosphate interaction (presented in Heldt and Piechula, 2011; Huber and Huber, 1992; Nielsen et al., 2004; Taiz and Zeiger, 2006) and brought them to a higher conceptual level, which is more practically sound and helpful for typical agronomic research. This conceptual phosphate-photosynthesis sub-model is presented in Fig. $4 B$ and is discussed in detail below along with the interpretation of the results of the field experiments presented in the previous section.
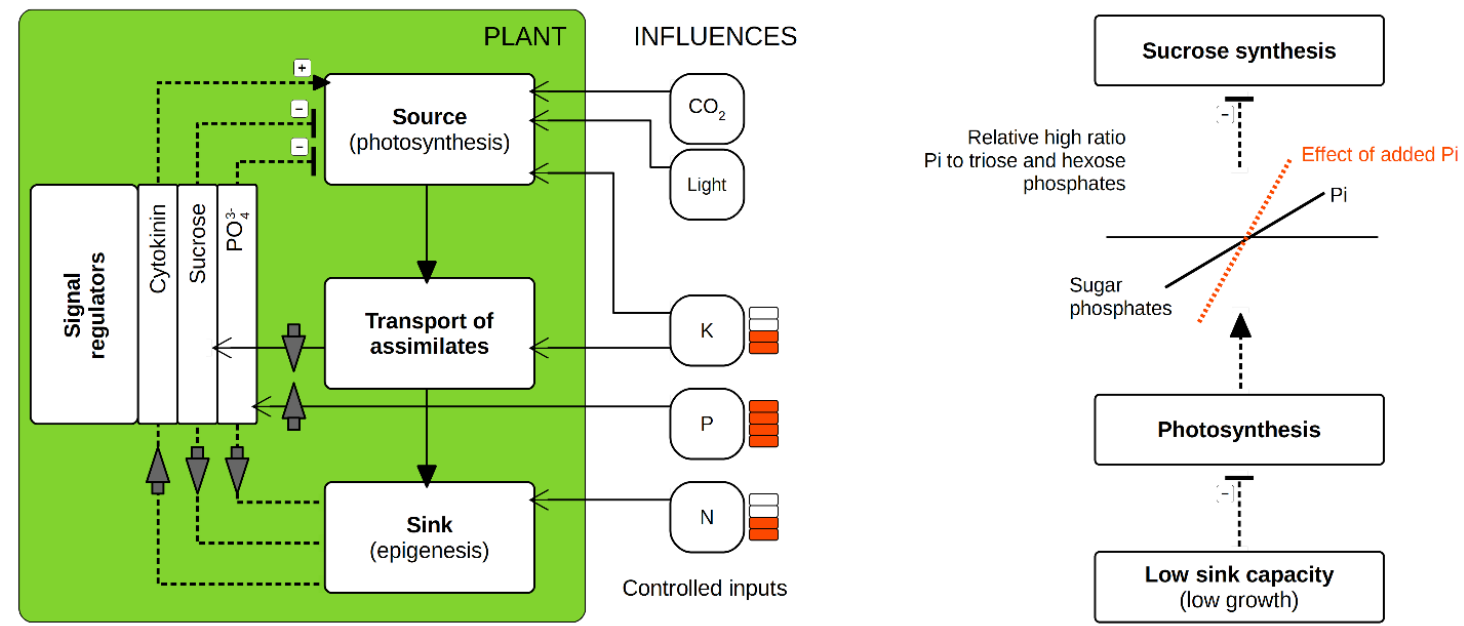

A
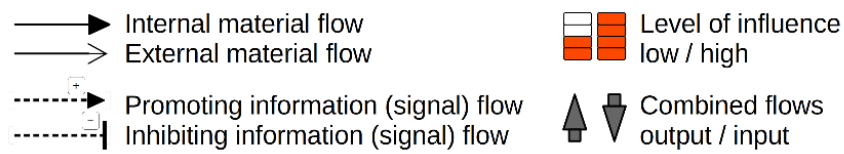

Figure 4. The causal loop diagrams for the conceptual model of photosynthesis and yield formation under specific environmental conditions $(A)$ and for the sub-model of phosphates interaction $(B)$

The results of field experiments show the positive influence of the total nitrogen concentration in soil on $S$. perfoliatum biomass $\left(r^{2}=0.58\right.$, see Fig. $\left.3 A\right)$. This increase in photosynthetic productivity while fertilizing with nitrogen is consistent with the fact that the $\mathrm{CO}_{2}$ and $\mathrm{NO}_{2}{ }^{-}$reductions carried by photosynthesis do not compete in terms of reduction, even under average illumination conditions (Alekhina et al., 1996). Moreover, it is known that with better root nutrition with nitrogen and when the entire root system is functioning well, the cytokinin signal is transmitted to the shoots, informing them about the need for more photoassimilates, so photosynthetic genes (including Rubisko, carbonic anhydrase, etc.) are activated, stomata are opened and, thus, photosynthesis is intensified (Lerbs et al., 1984; Paul and Foyer, 2001) (see Fig. 4A.: Informational flow " $\mathrm{N}$ - sink - cytokinine - source"). Plus, nitrogen is important for cell division processes and for the metabolic activity of acceptors in sucrose utilization (Nancy, 1994; Hirel et al., 2007). In growing acceptors, sucrose utilization depends on the supply of amino acids (Paul and Foyer, 2001). Because of these reasons, better nutrition with nitrogen can lead to the increased activity and sucrose consumption of acceptors, which lessens the suppression of photosynthesis and leads to a growth in 
productivity (see. Fig. 4A: Informational flow "N - sink (epigenesis) - sucrose source"). To sum up, in assessing productivity, a sufficiently large dispersion of yield at various chlorophyll a concentrations may be identified by differences in the activity of the acceptors, dictated by mineral nutrition, and then following by the signal's impact (gibberellin, sugar, etc.) on photosynthetic metabolism. The study shows that the mobile potassium concentration also influenced the $S$. perfoliatum biomass positively $\left(\mathrm{r}^{2}=\right.$ 0.55 , see Fig. $3 B$ ). The mobile potassium concentration varied greatly - from 165 to 330 $\mathrm{mg} / \mathrm{kg}$ in the soils of the field plots, i.e. the investigated soils ranged from medium to very high in regard to their potassium content (Mažvila et al., 2006). According to the literature, the influence of potassium on photosynthesis can occur by promoting the transport of assimilates from the leaves (Sandmann et al., 2011). Potassium promotes the removal of sucrose from leaves, and it reduces its concentration in leaves. Thus, this feedback control reduces the inhibition of photosynthesis and increases the entire plant's productivity (see. Figure 4A: Informational flow: "K - transport of assimilates sucrose - source").

Carbon and nitrogen intake in plants takes place according to a certain ratio, while maintaining a functional balance between the above-ground part and roots (Bastow Wilson, 1988). The required carbon assimilation, while maintaining a defined $\mathrm{C} / \mathrm{N}$ ratio is not only achieved by the photosynthetic intensity regulation described in the preceding paragraph, but also by the required formation of leaf surface area. It is known that the leaves of dicots have significantly longer growth zones than roots (Dale, 1982; Ivanov, 2011). It helps them to achieve the required growth rate of leaf surface area, and it also means an increase in photosynthetic productivity. The authors found that the meristem of monocots, specifically of grasses, may be about 3 times longer than now supposed (Šimkūnas et al., 2018). These observations additionally confirm the fact that carbon assimilation (either by changing the intensity of photosynthesis or the assimilating surface area) reaches its scale or level in different ways, which are affected by acceptor activity and mineral nutrition.

It should be mentioned that the limitation of photosynthesis and yield resulting from a phosphate deficiency is often encountered and almost exclusively described in the literature (see the review by Rychter and Rao, 2005). The inhibition of photosynthesis caused by a phosphate deficiency may occur especially in acidic soils, where phosphates are chemically bound and not readily available for plants. In this study, we found some unexpected negative influence on the $S$. perfoliatum biomass $\left(r^{2}=0.54\right)$ (see Fig. 3C) attributable to the mobile phosphate concentration in the soil. The mobile phosphorus concentrations in the soils ranged from 228 to $291 \mathrm{mg} / \mathrm{kg}$, i.e. these soils ranged from sufficient to high saturation according to the amount of phosphorus they contained (Mažvila et al., 2006).

It is known that reduced triose phosphate and glucose- 6 phosphate concentrations are accompanied by an increased phosphate concentration in the cytosol, thus, a relatively high phosphate content produces a signal indicating slow photosynthesis and a low metabolic level in plant cells (Nielsen et al., 2004). Since the sucrose synthesis pathway enzymes are inhibited by this signal (fructose 1,6-bisphosphatase is inhibited through fructose-2,6 phosphate, and sucrose phosphate synthase is inhibited by phosphate allosterically and through SnRK1), the sucrose synthesis rate is "adapted" to the low energy status of cells (see Fig. 4B) (Huber and Huber, 1992; Nielsen et al., 2004; Heldt and Piechula, 2011; Tognetti et al., 2013). As already mentioned, photosynthesis may be slowed down by a lack of acceptors activity when there is a deficiency of $\mathrm{N}$ and $\mathrm{K}$ or 
by other factors. During slowed down photosynthesis, when the external phosphate content available increases, the relative amount of phosphates increases even more in the cytosol. It such a way, it can provide a signal indicating extremely slow photosynthesis, which can lead to additional suppression of sucrose synthesis, and therefore, the plant biomass decreases (see. Figs. $4 B$ and $4 A$, informational flow: " $\mathrm{P}-$ signal $\mathrm{PO}_{4}{ }^{3-}-$ source"). Besides this, according to the literature data, when a plant is supplied with sufficient phosphates, an increase in their quantity may precipitate zinc (Zn) in plant tissues (Fageria, 2006; Hafeez et al., 2013). A lack of Zn or its low concentration increases phosphorus transport to the shoots and its concentration in leaves, which can cause the mentioned suppression of photosynthesis in plants (Mousavi et al., 2012). The detected suppression of photosynthesis by phosphates in the background of a nitrogen and potassium deficiency shows the importance of a balance of nutrient ions for the formation of plant productivity.

The essential role of acceptors in photosynthesis and yield limitation through sucrose and giberellin signalling is predicted by the conceptual model. The limitation of photosynthesis and yield attributable to signalling caused by high phosphate levels is also emphasized. Therefore, the informational flows, which are usually a subject of biochemical investigations, need to be incorporated in further field trial experiments as well, in order to facilitate the verification of the conceptual model. First, the specific growth characteristics of acceptors (meristemic growth on the morphometric, cytological, etc. levels) and the intensity of photosynthesis under various nutritional conditions should be evaluated, thus assessing the potential limitations of photosynthesis because of growth. In particular, it is worth estimating the change in photosynthesis intensity during the saltatory changes of the acceptors' growth under the influence of various stressors. Second, to prove that the yield limitation can be caused by the inhibition of the acceptors' growth, we propose that the hypothesis regarding the high concentration of sucrose and low concentration of cytokinin (signal compounds) in some compartments of leaves in the case of slow acceptors' growth be checked experimentally. Finally, the influence of large phosphate concentrations in a soil on photosynthetic productivity in the case of inhibited growth should be investigated in more detail.

In parallel, these regularities could be also validated under controlled conditions. In particular, an integrated climatic-hydroponic system developed by the authors provides all the necessary conditions required for such kind of validation experiments (Šimkūnas et al. 2018). The results of all these experiments should be directly used to refine the conceptual model proposed here. As the model expresses a generic conception of yield formation, it, therefore, can be used also for other energy plants and in a variety of environmental conditions. Meanwhile, the model can be refined according to a particular case, so it can reveal also a different causality for yield limitation. The energy plants are very fast growing, and the yield limitation through acceptors (i.e. the growing parts) could be more frequently met.

\section{Conclusions}

The designed conceptual model of $S$. perfoliatum productivity provides a significant methodological value while interpreting scarce and sometimes controversial empirical results. The model employs a systemic view of the concept of the "donor-acceptor" plant system and is based on the analysis of both material and informational 
relationships between the system components. To develop such a model of energy plant productivity, both empirical results and physiological assumptions along with known literature data are used. The representation of the field experimental data through use of the conceptual model provides a missing link between the field experiment's results and the molecular-biochemical investigations of the informational flows that regulate photosynthesis.

The field trial (empirical) results show the absence of dependence between the donor characteristic (chlorophyll a concentration) in regard to yield. According to the designed conceptual model, the yield differences may be explained by the differences in acceptor activity, which determines photosynthesis through signalling (informational flows).

The total nitrogen and mobile potassium concentrations in the soil positively influenced the productivity of $S$. perfoliatum. The article argues that nitrogen influenced the growth of biomass positively through the metabolic activation of acceptors, signalling the photosynthetic apparatus (through the increased cytokinin and the decreased sugar concentration). Meanwhile, the positive influence of potassium on biomass growth may express itself through the activation of the transport of assimilates from leaves (i.e. signalling through the decreased sugar concentration in leaves), thus promoting photosynthesis through feedback control.

In this study, some unexpected negative influence attributable to the mobile phosphate concentration in the soil on the $S$. perfoliatum biomass was found. To interpret this observation, the hypothesis of photosynthesis and yield limitation by signalling through high phosphate levels in the case of photosynthesis that has already slowed down is proposed.

To verify the conceptual model and test the underlying novice hypothesis, further research is needed. A detailed plan for that is delineated in the Discussion section. In particular, it is proposed that the study of plant information processes (carbohydrate, gibberellin and phosphate signalling) be incorporated in field research, along with synchronous measurements of the donor's (photosynthesis) activity characteristics and acceptor's growth rates.

\section{REFERENCES}

[1] Adegbidi, H. G., Volk, T. A., White, E. H., Abrahamson, L. P., Briggs, R. D., Bickelhaupt, D. H. (2001): Biomass and nutrient removal by willow clones in experimental bioenergy plantations in New York State. - Biomass and Bioenergy 20: 399-411.

[2] Allen, B. et al. (2014): Space for energy crops - assessing the potential contribution to Europe's energy future. - Institute for European Environmental Policy. - Report produced for BirdLife Europe, European Environmental Bureau and Transport \& Environment. IEEP, London.

[3] Alekhina, N. D., Krendeleva, T. E., Polesskaya, O. G. (1996): Relationships between nitrogen assimilation and photosynthesis in leaf cells of C3-plants. - Russian Journal of Plant Physiology 43: 119-130.

[4] Andrianova, I. E., Tarchevskii, I. A. (2000): Chlorophyll and productivity of plants. Moscow, Nauka (in Russian).

[5] Arnon, D. A. (1949): Copper enzymes in isolated chloroplasts. Polyphenoloxidase in Beta vulgaris. - Plant Physiology 24: 1-15. 
[6] Aurbacher, J., Benke, M., Formowitz, B., Glauert, T., Haiermann, M., Herrmann, C. et al. (2012): Energienpflanzen für Biogasanlagen. - Rostock, Fachagentur Nachwachsende Rohstoffe.

[7] Bastow Wilson, J. (1988): A review of evidence on the control of shoot:root ratio, in relation to models. - Annals of Botany 61: 433-449.

[8] Biertümpfel, A., Reinhold, G., Götz, R., Zorn, W. (2013): Leitlinie zur effizienten und umweltverträglichen Erzeugung von Durchwachsener Silphie (Leitlinie No. 1). Leitlinien der Thüringer Landesanstalt für Landwirtschaft, Jena.

[9] Borkowska, H., Molas, R., Kupczyk, A. (2009): Virginia Fanpetals (Sida hermaphrodita Rusby) Cultivated on Light Soil Height of Yield and Biomass Productivity. - Polish Journal of Environmental Studies 18: 563-568.

[10] Brown, R. H. (1988): Growth of the Green Plant. - In: Tesar, M. B. (ed.) Physiological Basis of Crop Growth and development, Madison, American Society of Agronomy: 153174.

[11] Chikov, V. I. (2008): Evolution of notions about relationships between photosynthesis and plant productivity. - Russ J of Plant Physiol. 55: 130-143.

[12] Dale, J. E. (1982): The growth of leaves. - London, Edward Arnold (Publishers) Ltd.

[13] Douglas, J. A., Follett, J. M., Halliday, I. R., Hughes, J. W., Par, C. R. (1987): Silphium: preliminary research on a possible new forage crop for New Zealand. - Proceedings Agronomy Society of New Zealand 17: 51-53.

[14] Eleuch, L., Rezgui, S., Daaloul, A. (2012): Induced physiological traits by NACL in Two barley cultivars. - Biologia Tunisie 7: 59-66.

[15] Fageria, V. D. (2006): Nutrient interactions in crop plants. - Journal of Plant Nutrition 24: $1269-1290$.

[16] Fatichi, S., Leuzinger, V., Körner, Ch. (2014): Moving beyond photosynthesis: from carbon source to sink-driven vegetation modeling. - New Phytologist 201: 1086-1095.

[17] Gansberger, M., Montgomery, L. F. R., Liebhard, P. (2015): Botanical characteristics, crop management and potential of Silphium perfoliatum $L$. as a renewable resource for biogas production: a review. - Industrial Crops and Products 63: 362-372.

[18] Grebe, S., Beleu, T., Döhler, H., Eckel, H., Frisch, J., Fröba, N. et al. (2012): Witzel Energiepflanzen: Daten für die Planung des Energiepflanzenanbaus. 2nd ed. - Darmstadt, KTBL.

[19] Hafeez, B., Khanif, Y. M., Saleem, M. (2013): Role of zinc in plant nutrition - a review. - American Journal of Experimental Agriculture 3: 374-391.

[20] Hall, D. O., Rao, K. K. (1994): Photosynthesis. 5th ed. - Cambridge, Cambridge University Press.

[21] Heldt, H-W., Piechula, B. (2011): Plant biochemistry. 4th ed. - London, Elsevier Academic Press.

[22] Hirel, B., Le, G. J., Ney, B., Gallais, A. (2007): The challenge of improving nitrogen use efficiency in crop plants: towards a more central role for genetic variability and quantitative genetics within integrated approaches. - Journal of Experimental Botany 58: 2369-2387.

[23] Hiscox, J. D., Israelstam, G. F. (1979): A method for the extraction of chlorophyll from leaf tissue without maceration. - Canadian Journal of Botany 57(12): 1332-1334.

[24] Huber, S. C., Huber, L. J. (1992): Role of sucrose-phosphate synthase in sucrose metabolism in leaves. - Plant Physiology 99: 1275-1278.

[25] Ivanov, V. B. (2011): Cellular mechanisms of plant growth. - Moscow, Nauka (in Russian).

[26] Jakienè, E., Spruogis, V., Romaneckas, K., Dautartė, A., Avižienytė, D. (2015): The bioorganic nano fertilizer improves sugar beet photosynthesis process and productivity. Žemdirbyste-Agriculture 102(2): 14-46.

[27] Jasinskas, A., Simonavičiūtè, R., Šiaudinis, G., Liaudanskienè I., Antanaitis, Š., Arak, M., Olt, J. (2014): The assessment of common mugwort (Artemisia vulgaris L.) and cup plant 
(Silphium perfoliatum L.) productivity and technological preparation for solid biofuel. Žemdirbyste-Agriculture 101: 19-26.

[28] Kowalski, R., Wolski, T. (2003): Evaluation of phenolic acid content in Silphium perfoliatum L. leaves, inflorescences and rhizomes. - Electronic Journal of Polish Agricultural Universities. http://ejpau.media.pl/series/volume6/ issue1/horticulture/art03.html.

[29] Lastdrager, J., Hanson, J., Smeekens, S. (2014): Sugar signals and the control of plant growth and development. - Journal of Experimental Botany 65: 799-807.

[30] Lawlor, D. W., Paul, M. J. (2014): Source/sink interactions underpin crop yield: the case for trehalose 6-phosphate/SnRK1 in improvement of wheat. - Frontiers in Plant Science 5: 418

[31] Lemoine, R., La Camera, S., Atanassova, R., Dédaldéchamp, F., Allario, T., Pourtau, N., Bonnemain, J. L., Laloi, M., Coutos-Thévenot, P., Maurousset, L., Faucher, M., Girousse, C., Lemonnier, P., Parrilla, J., Durand, M. (2013): Source-to-sink transport of sugar and regulation by environmental factors. - Frontiers in Plant Science 4: 1-21.

[32] Lerbs, S., Lerbs, W., Klyachko, N. L., Romanko, E. G., Kulaeva, O. N., Wollgiehn, R., Parthier, B. (1984): Gene expression in cytokinin-and light-mediated plastogenesis of Cucurbita cotyledons: ribulose-1,5-bisphosphate carboxylase/oxygenase. - Planta 162(4): 289-298.

[33] Maughan, M., Bollero, G., Lee, D. K., Darmody, R., Bonos, S., Cortese, L. et al. (2012): Miscanthus $\times$ giganteus productivity: the effects of management in different environments. - GCB Bioenergy 4: 253-265.

[34] Mažvila, J., Antanaitis, A., Lubytė, J., Arbačiauskas, J., Adomaitis, T., Mašauskas, V., Vaišvila, Z. (2005): Different methods of potassium analysis and their suitability for lithuanian soils. - Agronomijas vēstis Latvian Journal of Agronomy 8: 53-57.

[35] Mažvila, J., Vaičys, M., Buivydaite, V. (2006): Lietuvos dirvožemių makromorfologinè diagnostika. Dotnuva - Akademija, Lietuvos žemdirbystès institutas

[36] McKendry, P. (2002a): Energy production from biomass (part 1): overview of biomass. Bioresource Technology 83: 37-46.

[37] McKendry, P. (2002b): Energy production from biomass (part 3): gasification technologies. - Bioresource Technology 83: 55-63.

[38] Mokronosov, A. T. (1981): Ontogenical aspect of photosynthesis. - Nauka, Moscow (in Russian).

[39] Mousavi, S. R., Galavi, M., Rezaei, M. (2012): The interaction of zinc with other elements in plants: a review. - International Journal of Agriculture and Crop Sciences 24: 1881-1884.

[40] Nancy, L. (1994): Nutrient deficiencies and vegetative growth and crop productivity. In: Amarjit, B. (ed.) Mechanisms of Plant Growth and Improved Productivity Modern Approaches. Ludhiana, Punjab Agricultural University.

[41] Nielsen, T. H., Rung, J. H., Viladsen, D. (2004): Fructose-2,6-biphosphate: a traffic signal in plant metabolism. - Trends in Plant Science 9: 556-562.

[42] Paul, M. J., Foyer, C. H. (2001): Sink regulation of photosynthesis. - Journal of Experimental Botany 52: 1383-1400.

[43] Rossi, M., Bermudez, L., Carrari, F. (2015): Crop yield: challenges from a metabolic perspective. - Current Opinion in Plant Biology 25: 79-89.

[44] Rychter, A. M., Rao, I. M. (2005): Role of phosphorus in photosynthetic carbon metabolism. - In: Pessarakli, M. (ed.) Handbook of photosynthesis. New York, Marcel Dekker; 123-148.

[45] Sandmann, M., Skłodowski, K., Gajdanowicz, P., Michard, E., Rocha, M., GomezPorras, J. L., González, W., Corrêa, L. G., Ramírez-Aguilar, S. J., Cuin, T. A., van Dongen, J. T., Thibaud, J. B., Dreyer, I. (2011): The $\mathrm{K}^{+}$battery-regulating Arabidopsis $\mathrm{K}^{+}$ channel AKT2 is under the control of multiple post-translational steps. - Plant Signaling \& Behavior 6: 558-562. 
[46] Schoo, B., Wessel-Terharn, M., Schroetter, S., Schittenhelm, A. (2013): Vergleichende Untersuchung von Wurzelmerkmalen bei Silphie und Mais. - In: Pekrun, C., Wachendorf, M., Francke-Weltmann, L. (eds.) Nachhaltige Erzeugung von Nachwachsenden Rohstoffen, Mitt. Ges. Pflanzenbauwiss. Presented at the Tagung der Gesellschaft für Pflanzenbauwissenschaften e.V., Liddy Halm, Weihenstephan, 241-242.

[47] Stanford, G. (1990): Silphium perfoliatum (cup-plant) as a new forage. - In: Smith, D. D, Jacobs, C. A. (eds.) Recapturing a Vanishing Heritage. Presented at the 12th North American Prairie Conference, University of Northern Iowa, Cedar Falls, 33-38.

[48] Sterman, J. D. (2000): Business Dynamics: Systems thinking and modeling for a complex world. - McGraw Hill. ISBN 0-07-231135-5.

[49] Stockmann, F., Fritz, M. (2013): Einfluss von Standort und Herkunft auf das Errragspotenzial der Durchwachsenen Siphie (Silphium perfoliatum L.) unter bayerischen Anbaubedingungen. - In: Pecrun, C., Wachendorf, M., Francke-Weltmann, L. (eds.) Nachhaltige Erzeugung von Nachwachsenden Rohstoffen, Mitt. Ges. Pflanzenbauwiss. Presented at the Tagung der Gesellschaft für Pflanzenbauwissenschaften e. V. Liddy Halm, Weihenstephan, 146-147.

[50] Šiaudinis, G., Šlepetienė, A., Jasinskas, A., Karčauskienė, D. (2012): The evaluation of common mugwort (Artemisia vulgaris L.) and cup plant (Silphium perfoliatum L.) biomass and energetic productivity in Western Lithuania Albeluvisols. - ŽemdirbysteAgriculture 99(4): 357-362.

[51] Šiaudinis, G., Jasinskas, A., Šarauskis, E., Steponavičius, D., Karčauskienè, D., Liaudanskiene I. (2015): The assessment of Virginia mallow (Sida hermaphrodita Rusby) and cup plant (Silphium perfoliatum L.) productivity, physico-mechanical properties and energy expenses. - Energy 93: 606-612.

[52] Šimkūnas, A., Valašinaite, S., Denisov, V. (2018): Comparative systemic analysis of the cellular growth of leaves and roots in the controlled conditions. - Journal of Plant Physiology 220: 128-135.

[53] Taiz, L., Zeiger, E. (2006): Plant physiology, 4th ed. - Sunderland, Massachusetts: Sinauer Associates, Inc., Publishers.

[54] Tognetti, J. A., Pontis, H. G., Martinez-Noel, G. M. (2013): Sucrose signaling in plants: a world yet to be explored. - Plant Signaling \& Behavior 8(3): e23316.

[55] Yu, S. M., Lo, S. F., Ho, H. D. (2015): Source-Sink Communication: Regulated by Hormone, Nutrient, and Stress Cross-Signaling. - Trends in plant science 20: 844-857.

[56] Wrobel, M., Fraczek, J., Francik, S., Slipek, Z., Krzysztof, M. (2013): Influence of degree of fragmentation on chosen quality parameters of briquette made from biomass of cup plant Silphium perfoliatum L. - Proceedings of $12^{\text {th }}$ International Scientific Conference Engineering for Rural Development May 23-24, 2013, Latvia University of Agriculture: 653-657. 